\author{
Nikolay Bulychev
}

\title{
TAILOR-MADE BLOCK COPOLYMERS OF POLY (ACRYLIC ACID) AS PIGMENTS SURFACE MODIFICATION AGENTS
}

\author{
N.S. Kurnakov Institute of General and Inorganic Chemistry of Russian Academy of Sciences, \\ 31, Leninsky avenue, 119991 M oscow, Russia; nbulychev@mail.ru
}

Received: April 17, 2009

(C) Bulychev N., 2010

\begin{abstract}
The influence of the molecular architecture and the composition of block copolymers on their solid-liquid interface behaviour were investigated in detail. For this purpose, the surface modification of hydrophilic titanium dioxide and hydrophobic copper phthalocyanine pigments in aqueous dispersion by a series of amphiphilic block copolymers has been studied. As pigment stabilizers, amphiphilic copolymers consisting of poly(isobornyl acrylate) (PiBA) and poly(acrylic acid) (PAA) with welldefined molecular structure, controlled molecular weight and narrow polydispersity index have been synthesized by atom transfer radical polymerization (ATRP) using the macro-initiator strategy (to yield block copolymers). The dispersion stability, with and without the use of ultrasonic power, was studied by the electrokinetic sonic amplitude (ESA) method. Data obtained showed that the ultrasonic treatment causes a significant increase of the amount of a polymer absorbed on the particle surface, which is primarily attributed to the ultrasonically induced activation of the pigment surface.
\end{abstract}

Keywords: pigment dispersion, block copolymer, amphiphilic copolymers, polymer adsorption, ultrasonic treatment, electrokinetic sonic amplitude method, sedimentation, pigment surface modification.

\section{Introduction}

In the recent years, aqueous colloidal dispersions of pigments have attracted an increasing interest from both scientific and practical points of view. Amphiphilic polymers have shown to be effective stabilizers of various colloidal dispersions, such as pigments in aqueous media [1-9].

The colloidal stabilization of particulate aqueous dispersions by polymer surfactants is a result of the adsorption of amphiphilic macromolecules on the particle surface: often one block of the amphipolar block copolymer acts as an anchor. Depending on the constitutional characteristics of the block copolymer and the particulate system, mono- or multi-layers of certain structure and thickness which provide steric and/or electrostatic stabilization, are being formed.

The polymer adsorption on the particle surface itself is a result of specific interactions between structural motifs of the macromolecule and active sites on the particle surface. The chemical structure of the polymeric stabilizers has to be adjusted to the nature (e.g. hydrophilicity, charge, etc.) of each type of particles. Thus, comparative studies of the adsorption behaviour of polymers and the colloidal stabilization may be used as a sensitive approach to elucidate effects of the variation of the polymer structure on their behaviour at the solid-liquid interface.

It has been shown [7-9] that mechanical, in particular ultrasonic, treatment of aqueous dispersions of pigments in the presence of polymeric stabilizers leads to a significant enhancement of the stability of these dispersions. IR-analysis was used to prove that the thickness and stability of the polymer adsorption layers are increased and improved by the ultrasonification [7]. Parameters (thickness and structure) of polymer adsorption layers affected by the ultrasonic treatment have been investigated [9]. However, the effect of the ultrasonic treatment on the pigment-polymer interaction and structure formation of adsorption layers, especially for tailor-made amphiphilic copolymers, is not fully understood and needs further investigation for elucidating of the observed phenomena.

In the framework of this research, the aim of this paper is a detailed comparative study of the solid-liquid interface behaviour of well-defined amphiphilic polymers of various molecular architecture and different composition. For this reason, amphiphilic block copolymer structures are compared in the present study as stabilizers for aqueous colloidal dispersions of hydrophilic titanium dioxide $\left(\mathrm{TiO}_{2}\right)$ and hydrophobic copper phthalocyanine $(\mathrm{CuPc})$ pigments.

Block copolymers have been synthesized via the macroinitiator strategy. First, a given monomer is polymerized to a certain conversion followed by a 
purification step [10-16]. Then this polymer, usually carrying a functional end group, is used as a macroinitiator to initiate the polymerization of the second monomer. All synthetic procedure has been described elsewhere in detail [11-13].

As to studying polymer-particle interactions, electrokinetic sonic amplitude (ESA) measurements were shown to be a powerful method [9, 17-22] that provides information about the process of polymer adsorption onto solid particles. The desired information is derived from the dynamic mobility $\left(\mu_{D}\right)$ of the dispersed particle. $\mu_{D}$ represents the electrophoretic mobility of a particle in an alternating electric field. When such a field is applied to a colloidal system, it exerts an electric force on the particles, which causes them to move backwards and forwards. This motion generates the ESA signal, which in turn provides information about the particle motion, and thus on characteristics of the particle itself [19-22]. Practically, the applied field is measured directly, and the acoustic impedance of the suspension can be determined by measuring the reflection coefficient of a sound wave at the electrode-colloid boundary.

The advantage of reporting electroacoustic data in terms of dynamic mobility $\mu_{D}$ rather than reporting the raw ESA measurement data is that the dynamic mobility $\mu_{D}$ is a property of the suspension. Unlike the ESA signal, $\mu_{D}$ does not depend on the device geometry, neither on the acoustic properties of the device nor on the strength of the applied electric field.

Earlier studies of the change of $\mu_{D}$ of aqueous $\mathrm{TiO}_{2}$ dispersions upon addition of amphipolar polyelectrolytes have shown that ESA is a powerful method to reveal the nature of specific polymer-pigment interactions and how this is related to the molecular architecture of the employed polyelectrolytes [21-23]. In these investigations, the saturation concentration (SC), which is defined as the polymer concentration at which the curve obtained by plotting $\mu_{D} v S$. the polymer concentration reaches a plateau, was used for characterizing and quantifying the pigmentpolymer interactions.

\section{Experimental}

\subsection{M aterials}

Pigments: titanium dioxide rutil pigments Kronos 2310 with particle size $0.3 \mu$ and $\beta$-copper phthalocyanine $(\beta$-CuPc) with primary particle size $0.1 \mu \mathrm{m}$ were chosen.

Materials for synthesis of the PiBA-PAA block copolymers: Isobornyl acrylate (iBA, Aldrich, tech.) was purified by vacuum distillation $(394 \mathrm{~K} / 18 \mathrm{mmHg}$ ). 1-Ethoxyethyl acrylate (EEA) was synthesized by the acid catalyzed addition reaction of acrylic acid to ethyl vinyl ether as described previously [11-13], and purified by vacuum distillation $(303 \mathrm{~K} / 7 \mathrm{mbar}) . \mathrm{Cu}(\mathrm{I}) \mathrm{Br}$ (Aldrich,
$98 \%$ ) was purified by stirring with acetic acid, then by filtering and washing with methanol, and finally by drying in a vacuum oven at $343 \mathrm{~K}$. N,N,N',N", N"pentamethyldiethylenetriamine (PMDETA, Acros, 99+ \%) was distilled (358-359 K/12 mmHg). Methyl-2bromopropionate (MBP, Acros, $99 \%$ ) was used as received. Dimethyl 2,6-dibromoheptanedioate (DHD, Aldrich, 97 \%). (Trimethylsilyl)diazomethane (2.0M solution in diethyl ether, Aldrich) was used as received. Solvents were purchased from Aldrich (HPLC grade) and used without purification. All other chemicals were used as received.

\subsection{Techniques}

\subsubsection{Synthesis of PiBA-b-PAA block copolymers by ATRP}

The synthesis of the PiBA- $b$-PAA block copolymers consists of 3 steps: first, a PiBA macroinitiator is prepared, which is then used in the second step as a macroinitiator for the synthesis of the PiBA- $b$-PEEA block copolymer. In the third step, the PEEA segment is deprotected to PAA to yield the desired PiBA- $b$-PAA block copolymer. A typical synthetic procedure is illustrated for the preparation of sample BP14-7F4:

1) preparation of PiBA macroinitiator (HP14I4): polymerization of $i B A$ by $A T R P$

A typical polymerization procedure is as follows (HP14I4). A mixture of $0.11361 \mathrm{~mol}(24.0 \mathrm{ml})$ of the monomer iBA and $2.8402 \cdot 10^{-4} \mathrm{~mol}(0.059 \mathrm{ml})$ of PMDETA as the ligand was bubbled with $\mathrm{N}_{2}$ for $1 \mathrm{~h}$ to remove oxygen. Ethyl acetate as the solvent was also bubbled with $\mathrm{N}_{2}$ for $1 \mathrm{~h}$ to remove oxygen and $8 \mathrm{ml}(25 \mathrm{vol} \%)$ ethyl acetate was added to the reaction flask. $\mathrm{Cu}(\mathrm{I}) \mathrm{Br}$ $\left(2.8402 \cdot 10^{4} \mathrm{~mol}, 0.04074 \mathrm{~g}\right)$ was added and the reaction flask was placed in an oil bath at $363 \mathrm{~K}$. When the reaction mixture reached the desired reaction temperature, the polymerization was started by adding $5.6803 \cdot 10^{-4} \mathrm{~mol}$ $(0.063 \mathrm{ml})$ of methyl-2-bromopropionate as the initiator. Samples were withdrawn periodically to monitor the monomer conversion (by ${ }^{1} \mathrm{H}-\mathrm{NMR}$ ) and the average molecular weight (by SEC). The reaction was ended by cooling the reaction mixture in liquid nitrogen. The resulting polymer was dissolved in THF and copper was removed by passing the diluted reaction mixture over a column of neutral $\mathrm{Al}_{2} \mathrm{O}_{3}$ to remove the copper catalyst. After evaporating the excess solvent, the polymer was precipitated in methanol (10-fold excess).

2) preparation of PiBA-b-PEEA block copolymer (BP 14-7F4): synthesis of PiBA-b-PEEA by ATRP

A typical polymerization procedure is as follows (BP14-7F4). The monomer EEA was passed through a small column of basic alumina to remove traces of residual acid. The PiBA macroinitiator (HP14I4, $4.075 \mathrm{~g} ; 38.15 \cdot 10^{-5} \mathrm{~mol}$ ) was dissolved in the monomer EEA $\left(11 \mathrm{ml} ; 76.30 \cdot 10^{-3} \mathrm{~mol}\right)$, and oxygen was removed from the mixture by bubbling 
with $\mathrm{N}_{2}$ for $1 \mathrm{~h} . \mathrm{Cu}(\mathrm{I}) \mathrm{Br}\left(0.165 \mathrm{~g} ; 1.150 \cdot 10^{-3} \mathrm{~mol}, 3\right.$ eq. relative to initiator) was added under nitrogen atmosphere, and the reaction flask was immersed in an oil bath thermostated at $323 \mathrm{~K}$. Polymerization was started by adding PMDETA $\left(0.360 \mathrm{ml} ; 1.725 \cdot 10^{-3} \mathrm{~mol}\right)$ as the ligand. Samples were withdrawn periodically to monitor the monomer conversion (by ${ }^{1} \mathrm{H}-\mathrm{NMR}$ ) and the average molecular weight (by SEC). The reaction was ended by cooling the reaction mixture in liquid nitrogen. The block copolymer was dissolved in THF, and the copper was removed passing the diluted reaction mixture over a column of neutral $\mathrm{Al}_{2} \mathrm{O}_{3}$. Solvent was evaporated, and the polymer was precipitated in cold methanol (10-fold excess).

\section{3) deprotection of PiBA-b-PEEA to PiBA-b-PAA} by heating (BP14-7F4WD)

For thermolysis of the PiBA- $b$-PEEA block copolymers, a sample was spread out on a glass surface and heated in an oven at $353 \mathrm{~K}$ for $24 \mathrm{~h}$. TGA analysis confirmed total conversion of PiBA- $b$-PEEA to PiBA- $b$-PAA.

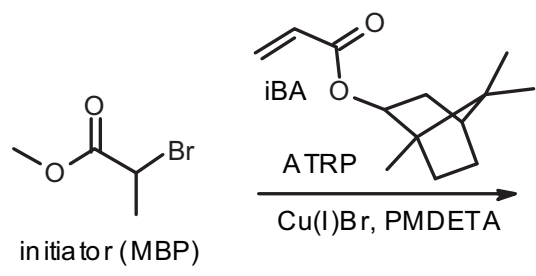

initia tor $(\mathrm{MBP})$
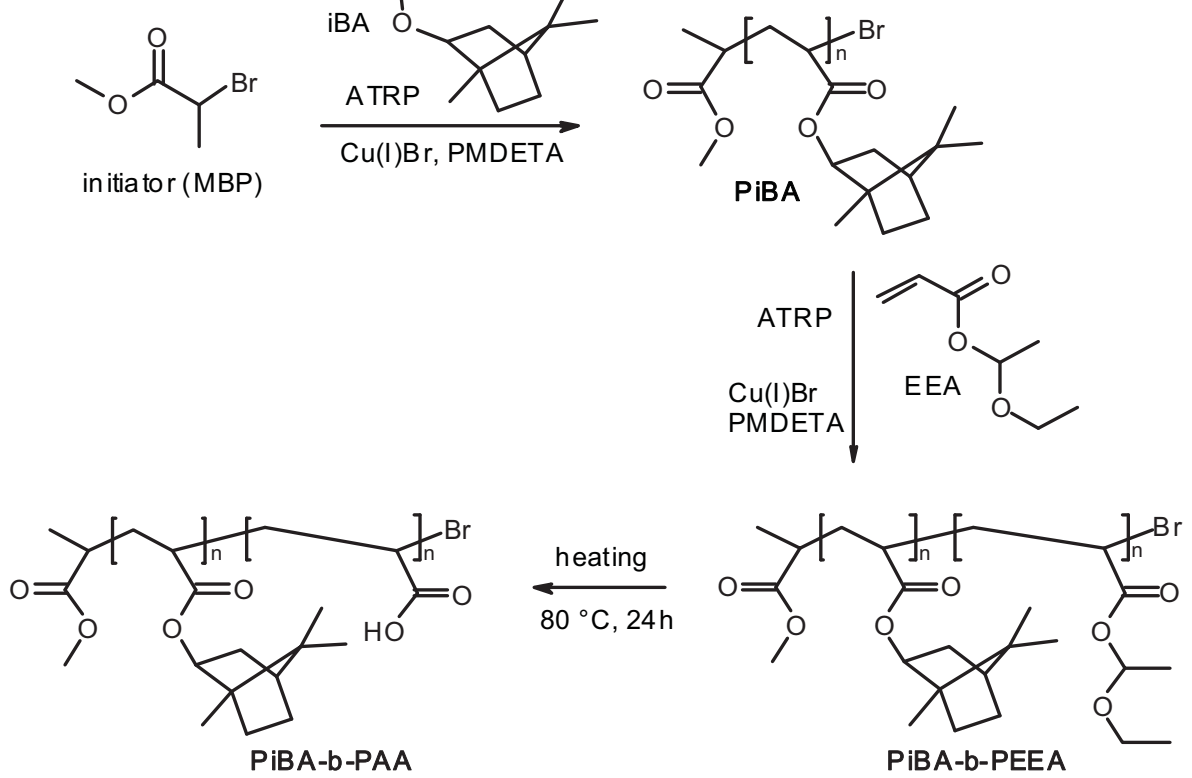

Fig. 1. Diagrammatic representation for the synthesis of PiBA-b-PAA block copolymers

Summary of the data and results of the synthesis of various PiBA macroinitiators

\begin{tabular}{|l|c|c|c|c|c|c|c|c|}
\hline Entry & Initiator & $\begin{array}{c}{[\mathrm{M}]_{0} /[\mathrm{In}]_{0} /} \\
{[\mathrm{Cu}]_{0} /[\text { ligand }]}\end{array}$ & $\begin{array}{c}\text { Temperature, } \\
\mathrm{K}\end{array}$ & $\begin{array}{c}\text { Time, } \\
\text { min }\end{array}$ & $\begin{array}{c}\text { Conversion, } \\
\%\end{array}$ & $\begin{array}{c}\mathrm{M}_{\mathrm{n}, \text { exp }}{ }^{*}, \\
\mathrm{~g} \cdot \mathrm{mol}^{-1}\end{array}$ & $M_{w} / M_{n}$ & Composition \\
\hline HP14F4 & MBP & $100 / 1 / 0.5 / 0.5$ & 363 & 45 & 19 & 3600 & 1.33 & $\mathrm{PiBA}_{17}$ \\
\hline HP14I3 & MBP & $200 / 1 / 0.5 / 0.5$ & 363 & 215 & 26 & 10600 & 1.24 & $\mathrm{PiBA}_{51}$ \\
\hline HP14I4 & MBP & $200 / 1 / 0.5 / 0.5$ & 363 & 120 & 26 & 10600 & 1.30 & $\mathrm{PiBA}_{51}$ \\
\hline HP14L1 & BHD & $200 / 1$ & 363 & 60 & 36 & 14900 & 1.17 & $\mathrm{PiBA}_{72}$ \\
\hline
\end{tabular}

* a conversion factor of 1.4 is applied. 


\subsubsection{Pigment stabilization techniques}

For the preparation of aqueous pigment dispersions, the pigment was added to water alone or together with the polymer dissolved in THF and dispersing of the pigment was first achieved by means of a laboratory stirrer (700 rpm for $10 \mathrm{~min}$ ). When ultrasonification was applied, the system was subsequently treated with ultrasound for 2 min with an ultrasonic generator Branson Sonifier B-12 with actual power of $1.5 \mathrm{~W} / \mathrm{cm}^{2}$.

Colloidal stabilization of the aqueous dispersions was monitored by sedimentation measurements of $1 \%$ dispersions of $\mathrm{CuPc}$ and $\mathrm{TiO}_{2}$. The pigment-polymer interaction and the polymer adsorption layer formation were investigated by electrokinetic sonic amplitude (ESA) measurements as described elsewhere [9, 21-23]. The particle size was measured by ESA [21]. Standard optical equipment was used for refractive index measurements.

\section{Results and Discussion}

\subsection{Synthesis of Various PiBA-b-PAA Block Copolymers for Pigment Stabilization}

PiBA- $b$-PAA block copolymers with various compositions were chosen as polymeric stabilizers for $\mathrm{TiO}_{2}$ and $\mathrm{CuPc}$ aqueous dispersions. The PiBA segment acts as the hydrophobic part, while PAA is the hydrophilic part.

The synthesis of the PiBA- $b$-PAA block copolymers by atom transfer radical polymerization (ATRP) consists of 3 steps (see Fig. 1): first, a PiBA macroinitiator is prepared, which is then used in the second step as a macroinitiator for the synthesis of the PiBA- $b$-PEEA block copolymer. In the third step, the PEEA segment is deprotected to PAA to yield the desired amphiphilic PiBA- $b$-PAA block copolymer. For a detailed discussion about the controlled radical polymerization of PiBA polymers by ATRP, we refer to our previously published papers [11-13].
A summary of the data and results of the synthesis of the various PiBA polymers that are used as macroinitiators for the block copolymerizations is given in Table 1. All polymerizations of iBA were carried out in $25 \mathrm{vol} \%$ of ethyl acetate as solvent. All polymerisations were performed with a proper control over the molecular weight, while relatively narrow polydispersities $\left(M_{w} / M_{n}\right)$ were obtained. Conversions were kept low in order to retain maximal bromine chain end functionality, which is necessary for the synthesis of well-defined block copolymers.

The above synthesized PiBA polymers were used as a macroinitiator to polymerize EEA as the second block. In this way, PiBA- $b$-PEEA block copolymers are obtained with different molecular composition. A summary of the data and results of the synthesis of various PiBA- $b$-PEEA block copolymers is given in Table 2 .

A kinetic analysis of the block copolymerization shows the controlled behaviour of the polymerization reaction. The increase of the molecular weight as a function of conversion shows a linear behaviour, while polydispersity decreases during the polymerization reaction (see Fig. 2a). However, the first order kinetic plot shows a deviation from linearity after some time. This is due to partial deprotection of the EEA to acrylic acid that forms a complex with the $\mathrm{Cu}$ catalyst, reducing the actual catalyst concentration, and thus lowering the concentration of radicals in the system (see Fig. 2b). In SEC analysis, almost no unreacted macroinitiator could be observed (see Fig. 3). This means that a pure block copolymer is obtained, and proves that the polymerization of iBA (synthesis of the PiBA macroinitiator) under the used polymerization conditions occurs with only minimal loss of bromine end group.

After synthesis, the PiBA- $b$-PEEA block copolymers are converted to the corresponding PiBA- $b$-PAA block copolymers by a heating step. All polymers were spread out on a glass surface and heated in an oven at $353 \mathrm{~K}$ for 24h. ${ }^{1} \mathrm{H}$ NMR and TGA experiments confirmed total

Table 2

Summary of the data and results of the synthesis of various PiBA-b-PAA block copolymers

\begin{tabular}{|c|c|c|c|c|c|c|c|c|c|}
\hline Entry & Initiator & $\begin{array}{c}{[\mathrm{M}]_{0} /[\mathrm{In}]_{0} /} \\
{[\mathrm{Cu}]_{0} /[\mathrm{ligand}]}\end{array}$ & $\begin{array}{c}\text { Temperature, } \\
\mathrm{K}\end{array}$ & $\begin{array}{c}\text { Time, } \\
\mathrm{min}\end{array}$ & $\begin{array}{c}\text { Conversion, } \\
\%\end{array}$ & $\begin{array}{c}\mathrm{M}_{\mathrm{n}, \mathrm{exp},} \\
\mathrm{g} \cdot \mathrm{mol}^{-1}\end{array}$ & $M_{w} / M_{2}$ & Composition* & $\begin{array}{c}\text { Composition (after } \\
\text { deprotection) }\end{array}$ \\
\hline $\begin{array}{c}\text { BP14- } \\
\text { 7F3 }\end{array}$ & HP14I3 & $200 / 1 / 3 / 4.5$ & 333 & 160 & 25 & 16100 & 1.35 & $\mathrm{PiBA}_{51}-\mathrm{PEEA}_{56}$ & $\mathrm{PiBA}_{51}-\mathrm{PAA}_{56}$ \\
\hline $\begin{array}{c}\text { BP14- } \\
\text { 7F4 }\end{array}$ & HP14I4 & $200 / 1 / 3 / 4.5$ & 333 & 80 & 14 & 11300 & 1.32 & $\mathrm{PiBA}_{51}-\mathrm{PEEA}_{30}$ & $\mathrm{PiBA}_{51}-\mathrm{PAA}_{30}$ \\
\hline $\begin{array}{c}\text { BP14- } \\
\text { 7I1 }\end{array}$ & HP14F4 & $150 / 1 / 3 / 4.5$ & 343 & 245 & 45 & 14100 & 1.22 & $\mathrm{PiBA}_{17}-\mathrm{PEEA}_{72}$ & $\mathrm{PiBA}_{17}-\mathrm{PAA}_{72}$ \\
\hline $\begin{array}{c}\text { BP7- } \\
\text { 14-7A1 }\end{array}$ & HP14L1 & $300 / 1 / 3 / 4.5$ & 343 & 395 & 19 & 15100 & 1.18 & $\begin{array}{c}\mathrm{PEEA}_{25}-\mathrm{PiBA}_{72}- \\
\mathrm{PEEA}_{25}\end{array}$ & $\begin{array}{c}\mathrm{PAA}_{25}-\mathrm{PiBA}_{72-} \\
\mathrm{PAA}_{25}\end{array}$ \\
\hline
\end{tabular}

* composition was determined from ${ }^{1} \mathrm{H}$ NMR analysis. 

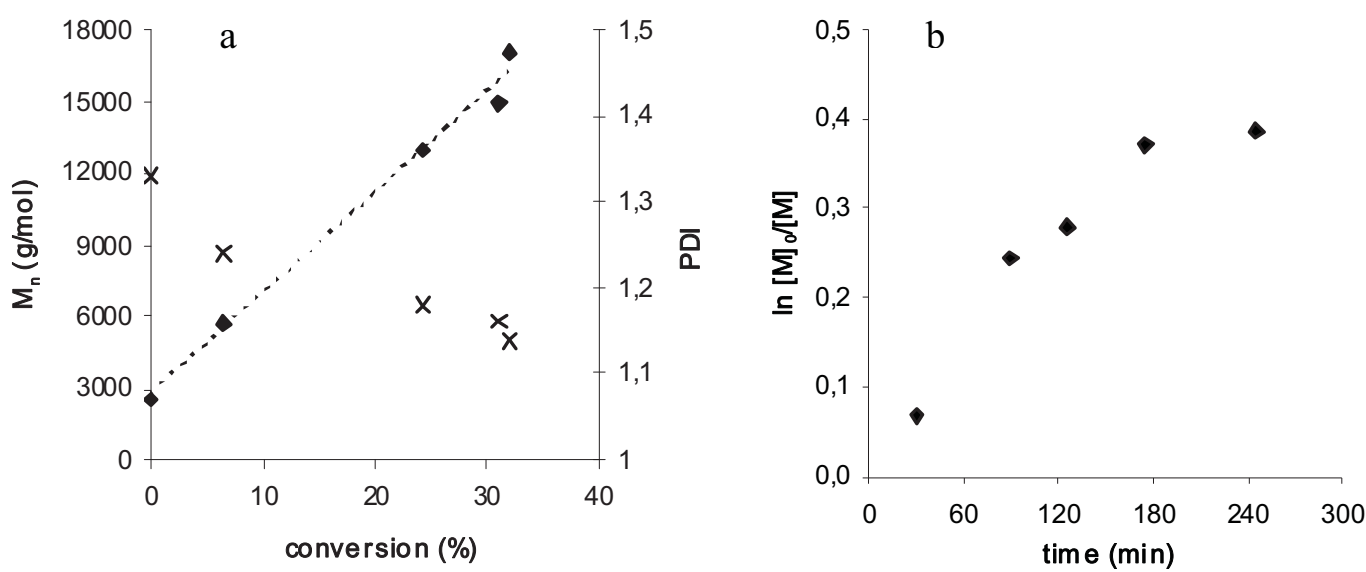

Fig. 2. Evolution of the average molar mass $\left(M_{n}\right)$ and polydispersity (PDI) as a function of conversion of the polymerization of EEA starting from a PiBA macroinitiator [BP14-7I1, Table 2] (dotted line $=$ trend line) (a) and first order kinetic plot (b)

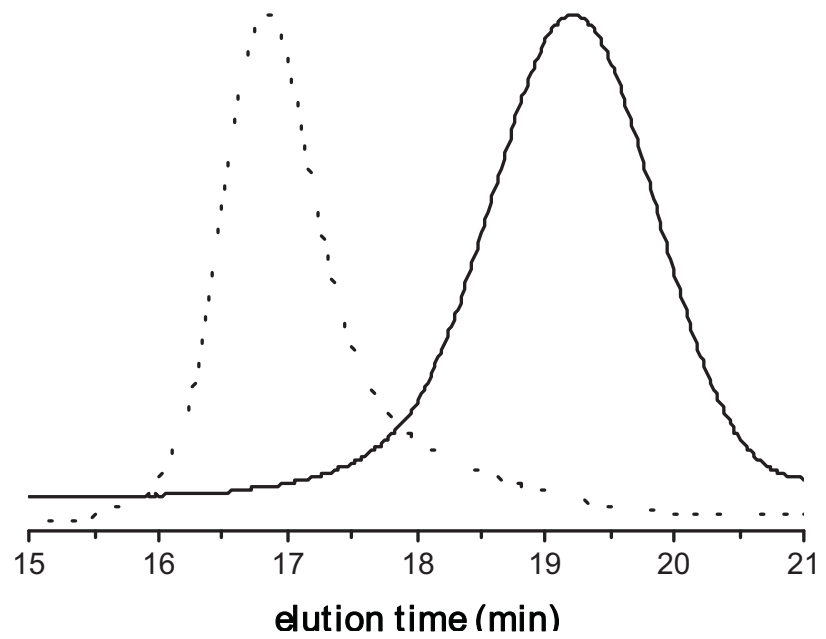

Fig. 3. SEC analysis of $\mathrm{PiBA}_{17}$ macroinitiator (solid line) and the corresponding $\mathrm{PiBA}_{17}-b$ - $\mathrm{PEEA}_{72}$ block copolymer (dotted line) [BP14-7I1, Table 2]

conversion of PiBA- $b$-PEEA to PiBA- $b$-PAA. A TGA analysis of sample $\mathrm{PiBA}_{51}-b$ - $\mathrm{PEEA}_{56}$ before and after the heating step is shown in Fig. 4. For the unprotected $\mathrm{PiBA}_{51^{-}}$ $b$-PEEA ${ }_{56}$ sample, TGA analysis reveals a weight decrease at $423 \mathrm{~K}$, which corresponds to the deprotection step to yield $\mathrm{PiBA}_{51}-b$ - $\mathrm{PAA}_{56}$ with loss of vinyl ether (volatile compound, $\mathrm{bp}=306 \mathrm{~K})$.

\subsection{Pigment Stabilization Experiments}

Data reported in literature [7, 9, 24], show that mechanical, in particular, ultrasonic treatment of aqueous dispersions of pigments in the presence of polymeric stabilizers leads to a significant enhancement of the stability of these dispersions as compared to dispersions prepared

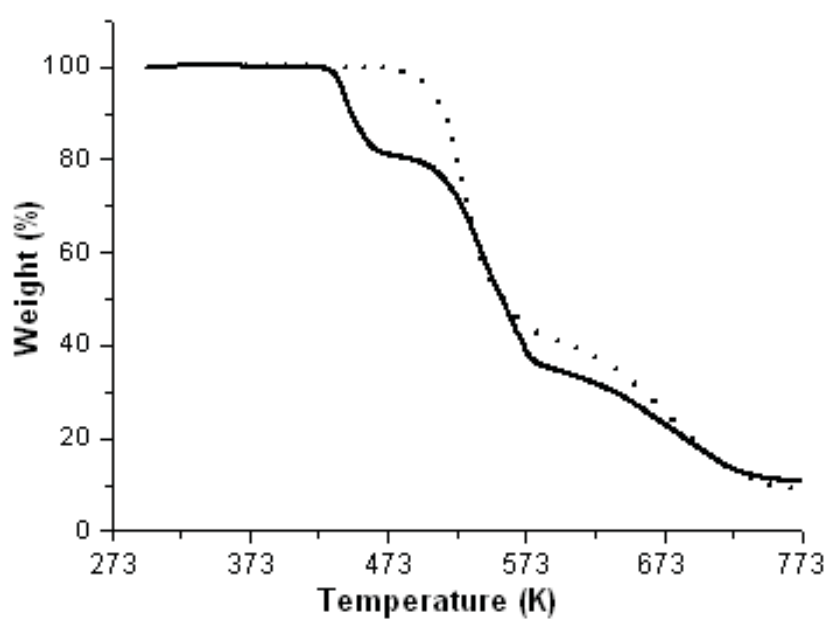

Fig. 4. TGA analysis of $\mathrm{PiBA}_{51}-b$ - $\mathrm{PEEA}_{56}$ (before deprotection, solid line) and $\mathrm{PiBA}_{51}-b-\mathrm{PAA}_{56}$ (after deprotection by heating at $353 \mathrm{~K}$ for $24 \mathrm{~h}$, dotted line)

[BP14-7F3, Table 2]

without ultrasonic treatment. It was proven by IR-analysis that the thickness and stability of the polymer adsorption layers were increased and improved by the ultrasonification [7]. Parameters of polymer adsorption layers affected by the ultrasonic treatment were investigated [9]. However, the effect of the ultrasonic treatment on the pigmentpolymer interaction and polymer adsorption, especially for novel tailor made amphipolar copolymers is still obscure and needs further investigation for better elucidation of the phenomena observed.

First, sedimentation measurements for $\mathrm{TiO}_{2}$ and $\mathrm{CuPc}$ aqueous dispersions stabilized by a series of tailormade amphipolar copolymers containing PiBA and PAA segments in the presence and absence of ultrasonic treatment have been carried out. These data are presented in Table 3 and 4. 
Table 3

Sedimentation stability of $\mathrm{TiO}_{2}$ aqueous dispersions stabilized by PiBA-b-PAA block copolymers

\begin{tabular}{|c|c|c|}
\hline \multirow{2}{*}{ Polymer } & \multicolumn{2}{|c|}{ Suspension stability (half-time of the sedimentation, days) } \\
\cline { 2 - 3 } & Without mechanical treatment & After ultrasonic treatment \\
\hline PiBA $_{72}$ & 0.2 & 4 \\
PAA $_{28}$ & 2 & 10 \\
PiBA $_{51}-b-\mathrm{PAA}_{56}$ & 2 & 14 \\
$\mathrm{PiBA}_{51}-b-\mathrm{PAA}_{30}$ & 0.1 & 1 \\
$\mathrm{PiBA}_{17}-b-\mathrm{PAA}_{72}$ & 3 & 30 \\
$\mathrm{PAA}_{25}-b-\mathrm{PiBA}_{72}-b-\mathrm{PAA}_{25}$ & 0.3 & 7 \\
\hline
\end{tabular}

Table 4

Sedimentation stability of CuPc aqueous dispersions stabilized by PiBA-b-PAA block copolymers

\begin{tabular}{|c|c|c|}
\hline \multirow{2}{*}{ Polymer } & \multicolumn{2}{|c|}{ Suspension stability (half-time of the sedimentation, days) } \\
\cline { 2 - 3 } & Without mechanical treatment & After ultrasonic treatment \\
\hline PiBA $_{72}$ & 3 & 10 \\
PAA $_{28}$ & 0.3 & 2 \\
PiBA $_{51}-b-\mathrm{PAA}_{56}$ & 4 & 20 \\
$\mathrm{PiBA}_{51}-b-\mathrm{PAA}_{30}$ & 5 & 45 \\
$\mathrm{PiBA}_{17}-b-\mathrm{PAA}_{72}$ & 0.2 & 5 \\
$\mathrm{PAA}_{25}-b-\mathrm{PiBA}_{72}-b-\mathrm{PAA}_{25}$ & 3 & 14 \\
\hline
\end{tabular}

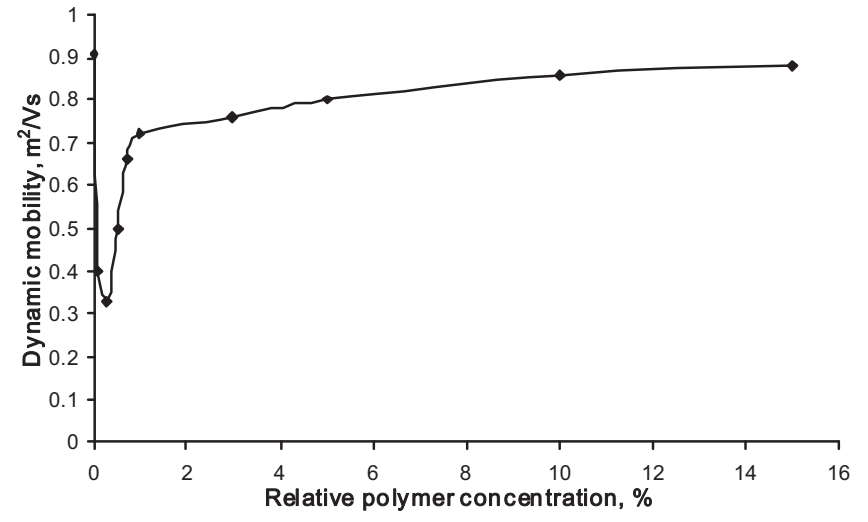

Fig. 5. Dependence of the dynamic mobility on the relative concentration of $\mathrm{PiBA}_{17}-b-\mathrm{PAA}_{72}$ for $1 \mathrm{wt} \% \mathrm{TiO}_{2}$ aqueous dispersion without ultrasonic treatment

First, as one can see from Tables 3 and 4, all employed copolymers allow to obtain pigment dispersions even in the absence of ultrasonic action while recent data on the application of PMVE containing block copolymers showed the impossibility to obtain dispersions without mechanical treatment [8]. It could be ascribed to the fact that THF used as a polymer solvent in the present study is known to create micelles with water providing the transport of a polymer to the pigment surface. Second it is evident that, irrespective of the constitution of the copolymer, the ultrasonification substantially improves the dispersion

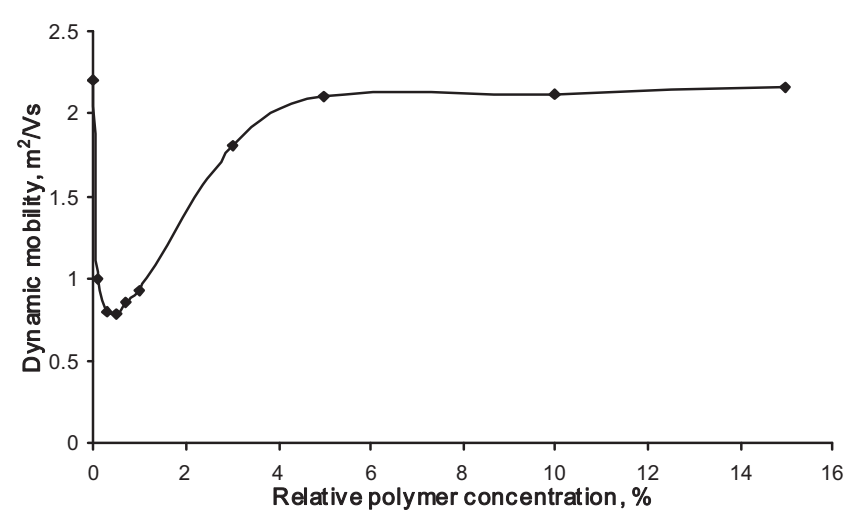

Fig. 6. Dependence of the dynamic mobility on the relative concentration of $\mathrm{PiBA}_{17}-b-\mathrm{PAA}_{72}$ for $1 \mathrm{wt} \% \mathrm{TiO}_{2}$ aqueous dispersion after ultrasonic treatment

stability as reflected from the comparison of the sedimentation half times of the non-treated and treated systems. The data also infer that there is an optimal copolymer structure with regard to the block length ratio; this is in accordance with previously discussed constitutional effects [8]. Third, there is a distinct effect of the pigment surface nature on the polymer structure acting as the best stabilizer: for hydrophilic $\mathrm{TiO}_{2}$ dispersions, $\mathrm{PiBA}_{17}-b$ - $^{-\mathrm{PAA}_{72}}$ with long PAA block showed good stabilization, for hydrophobic $\mathrm{CuPc}, \mathrm{PiBA}_{51}-b-\mathrm{PAA}_{30}$ with the ratio $\mathrm{PiBA} / \mathrm{PAA} \sim 2$ revealed the best result. 


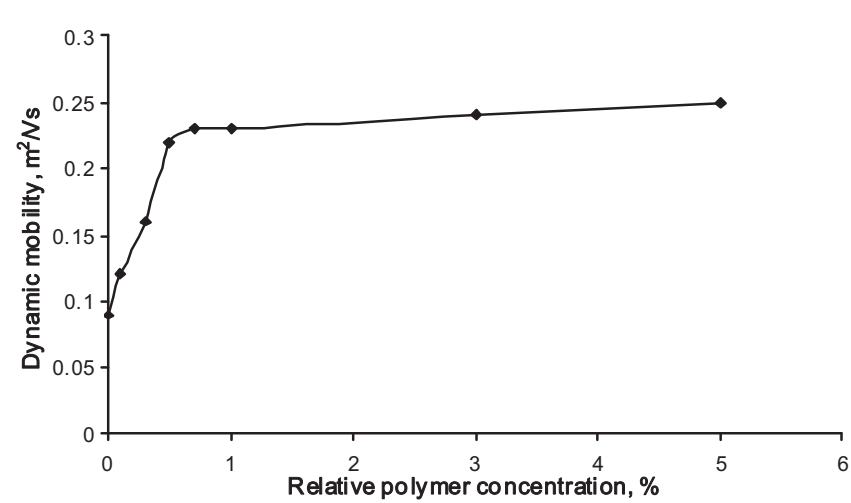

Fig. 7. Dependence of the dynamic mobility on the relative concentration of $\mathrm{PiBA}_{51}-b-\mathrm{PAA}_{30}$ for $1 \mathrm{wt} \% \mathrm{CuPc}$ aqueous dispersion without ultrasonic treatment

ESA measurements of aqueous dispersions of $\mathrm{TiO}_{2}$ and $\mathrm{CuPc}$, stabilized by block copolymers of PiBA- $b$-PAA, give quantitative information about the process of adsorption of polymers as reflected first from the dependence of the dynamic mobility $\mu$ on the relative polymer concentration [21-23] as shown in Figs. 5 and 6, and second - from the comparison of this dependency for systems without and with ultrasonic treatment.

As one can see from the comparison of Figs. 5 and 6, ultrasonic treatment has a distinct effect on the behaviour of the particulate pigment-polymer suspension. Without ultrasonic action, the formation of a polymeric adsorption layer on the pigment surface seems to be reached at 1 wt $\% \mathrm{PiBA}_{17}-b$ - $\mathrm{PAA}_{72}$ in relation to the pigment concentration (saturation concentration as indicated by the unchanged dynamic mobility with further increase of polymer concentration). In the presence of ultrasonic action, first the initial dynamic mobility of the pristine $\mathrm{TiO}_{2}$ is much higher, and the saturation concentration of polymer is only reached at about $5 \%$. Further addition of polymer does not affect the dynamic mobility. The decrease of the dynamic mobility after addition of small amounts of a polymer is in agreement with the data obtained for PS- $b$ PAA block copolymers [21].

Obviously the ultrasonic action not only increases the pigment surface by creating more fine dispersion but also activates the pigment surface leading to an ultimately higher polymer adsorption in comparison to the non-treated samples. Similar results were obtained for $\mathrm{CuPc}$ aqueous dispersions as can bee seen from Figs. 7 and 8 .

Comparing the values of saturation concentration without and after ultrasonic treatment, one can infer that the amount of polymer adsorbed on the particle surface significantly increases when ultrasonification is applied. In this context it has to be considered that the ultrasonic treatment leads to a finer dispersion by decreasing the particle size, and, consequently leading to an increase of the surface area prone to polymer deposition. Thus both

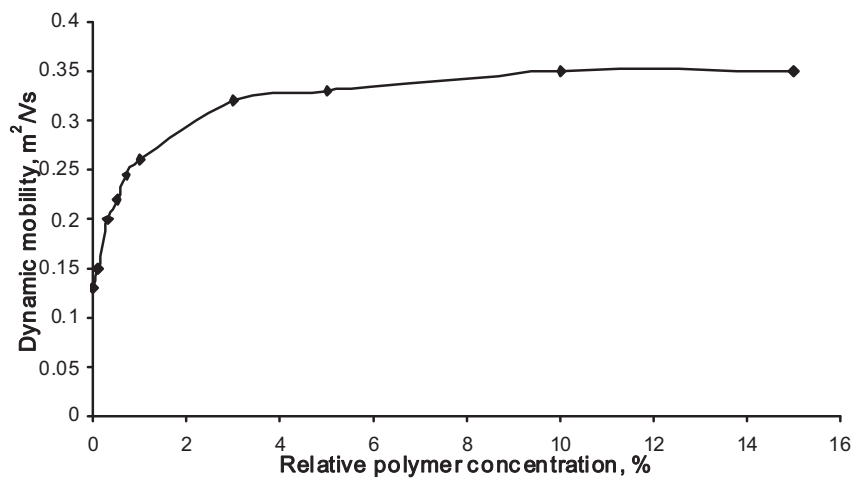

Fig. 8. Dependence of the dynamic mobility on the relative concentration of $\mathrm{PiBA}_{51}-b-\mathrm{PAA}_{30}$ for $1 \mathrm{wt} \% \mathrm{CuPc}$ aqueous dispersion after ultrasonic treatment

the increase in the total surface area of the dispersed particles and a possible ultrasonically induced activation of the particle surface must be considered as being responsible for the observed effects.

In order to get some quantitative information about the polymer adsorption as revealed from the ESA data, and to correlate the amount of polymer adsorbed with the dispersing conditions, calculations of the surface area of the pristine pigment particle and of the polymer coated particle were done for both of the systems without and with ultrasonic treatment and related to the amount of adsorbed polymer.

In these calculations it was assumed that the pigment particle has spherical shape, and that the maximum polymer adsorption is indicated by the saturation concentration SC; this saturation concentration is reached when the dynamic mobility vs. relative polymer concentration curve (Figs. 5-8) becomes more or less parallel to the abscissa and does not change much for increasing polymer concentration [21].

First, the total surface area $S_{\text {tot }}$ of the particles with surface area $S_{\text {part }}$ is obtained from the measured average particle diameter $d_{\text {part }}$ and the particle number in the dispersion. Since the saturation concentration SC as obtained by ESA measurements corresponds to the total mass of amphiphilic polymer that is adsorbed on the dispersed particles, the increased particle diameter (due to the adsorbed polymer) and thus the thickness of the polymer adsorption layer can be calculated as well. For the background and the equations for calculations of the data compiled in Table 5 it is referred to the previously published paper [9].

The comparison of the experimentally measured diameter $d_{\text {part }}$ of the polymer coated particles which were obtained by application of ultrasonification (column 3 in Table 5) and without ultrasonification (column 2 in Table 5) shows that smaller particles resulted from the ultrasonification; this was to be expected since ultrasonic 
Effect of ultrasonic treatment on the particle diameter $d_{\text {pare }}$ and effect of ultrasonic treatment on the increase of the particle surface area $\left(S_{\text {tot }}\right)$ as well as on the saturation concentration (SC) of added amphiphilic copolymer as expressed by the corresponding $S_{\text {tot }}$ and SC ratio; the indexes 1 and 2 refer to the non-treated (1) and ultrasonically treated (2) sample

\begin{tabular}{|c|c|c|c|c|}
\hline \multirow[b]{2}{*}{ System } & \multicolumn{2}{|c|}{$\begin{array}{l}\text { Averaged particle diameter } \\
\qquad\left(d_{\text {part }}\right), \mu \mathrm{m}\end{array}$} & \multirow{2}{*}{$\begin{array}{l}\text { Ratio between particle } \\
\text { surface area with and } \\
\text { without ultrasonic } \\
\text { treatment } \\
\left(S_{\text {tot } 2} / S_{\text {totl }}\right)\end{array}$} & \multirow{2}{*}{$\begin{array}{c}\text { Ratio between } \\
\text { saturation } \\
\text { concentration with } \\
\text { and without } \\
\text { ultrasonic treatment } \\
\quad\left(\mathrm{SC}_{2} / \mathrm{SC}_{1}\right)\end{array}$} \\
\hline & $\begin{array}{l}\text { Without } \\
\text { ultrasonic } \\
\text { treatment }\end{array}$ & $\begin{array}{l}\text { After ultrasonic } \\
\text { treatment }\end{array}$ & & \\
\hline $\mathrm{TiO}_{2}+\mathrm{PiBA}_{17}-b-\mathrm{PAA}_{72}$ & 1.2 & 0.6 & 2 & 5 \\
\hline $\mathrm{CuPc}+\mathrm{PiBA}_{51}-b-\mathrm{PAA}_{30}$ & 0.8 & 0.3 & 2.7 & 6 \\
\hline
\end{tabular}

Table 6

Thicknesses $\mathrm{d}$ of the adsorption layer of the amphipolar copolymer on $\mathrm{TiO}_{2}$ and $\mathrm{CuPc}$ surface for ultrasonically treated and non-treated dispersions as calculated on the basis of the saturation concentration SC obtained from the ESA measurements (see Table 3)

\begin{tabular}{|c|c|c|c|}
\hline System & $\begin{array}{c}\text { Thickness d of the } \\
\text { adsorption layer without } \\
\text { ultrasonic treatment, nm }\end{array}$ & $\begin{array}{c}\text { Thickness d of the } \\
\text { adsorption layer after } \\
\text { ultrasonic treatment, nm }\end{array}$ & $\begin{array}{c}\text { Ratio between the } \\
\text { thicknesses of treated } \\
\text { and non-treated } \\
\text { samples }\end{array}$ \\
\hline $\begin{array}{c}\mathrm{TiO}_{2}+\mathrm{PiBA}_{17}-b-\mathrm{PAA}_{72} \\
\mathrm{CuPc}+\mathrm{PiBA}_{51}-b-\mathrm{PAA}_{30}\end{array}$ & 5.5 & 13.6 & 3.2 \\
& 1 & 2.3 & 2.3 \\
\hline
\end{tabular}

treatment is known to cause a breaking of agglomerates/ aggregates present in pigment slurries.

Whereas the particle surface area $S_{\text {tot }}$ increases upon ultrasonic treatment by about a factor of 2 (minimum) and up to a factor of about 2.7 (see column 4 of Table 5), the saturation concentrations SC as derived from the experimental curves Figs. 5-8 is 5 to 6 times higher for the ultrasonically treated systems as compared to the nontreated systems (see column 5 of Table 5); in other words, the SC ratio is about three times larger than the $S_{\text {tot }}$ ratio (compare columns 4 and 5 in Table 5). This indicates that the amount of polymer adsorbed per unit of the particle surface after ultrasonic treatment is higher as compared to non-treated samples.

The thicknesses of the adsorbed polymer layer as obtained for the $\mathrm{TiO}_{2}$ and $\mathrm{CuPc}$ pigment dispersions under conditions of ultrasonic treatment in comparison to the systems without ultrasonic treatment are compiled in Table 6 . Thicker adsorption layers observed for the ultrasonically treated systems confirm that an activation of the pigment surface occurs by the action of ultrasonic power.

A general conclusion that can be drawn from the data compiled in Table 5 and Table 6 is that increase of the thickness of the polymer adsorption layers upon ultrasonic treatment is confirmed from both the information obtained from the ESA measurements and from the calculations of the particle surface.

In particular, the data allow to conclude that ultrasonic treatment of aqueous inorganic pigment dispersions is a powerful method for pigment surface modification leading first to an activation of the pigment surface; as a consequence, improvement of the pigmentpolymer interaction is achieved, which results in the creation of polymer adsorption layers of high thickness.

\section{Conclusions}

Poly(isobornyl acrylate)- $b$-poly(acrylic acid) were synthesized in a controlled way by ATRP by employing the 1-ethoxyethyl protecting group strategy. Next, these block copolymers were used in pigment stabilization experiments. It was possible to stabilize hydrophobic as well as hydrophilic dispersion. ESA measurements were performed in order to give quantitative information about the process of adsorption of polymers. Increase of the thickness of the polymer adsorption layers upon ultrasonic treatment is confirmed from both the information obtained from the ESA measurements and from the calculations of the particle surface.

\section{Acknowledgements}

The author expresses his thanks to the research group of Prof. F.E. Du Prez (University of Ghent, Belgium) for donation of PiBA- $b$-PAA copolymers and to the research group of Prof. Claus D. Eisenbach (University of Stuttgart, Germany) for valuable help in experimental studies. 


\section{References}

[1] Holmberg K., Johnsson B., Kronberg B. and Lindman B.: Surfactants and polymers in aqueous solution; $2^{\text {nd }}$ edn., John Wiley \& Sons, Chichester 2003.

[2] Netz R. and Andelman D.: Phys. Rep., 2003, 380, 1.

[3] Somasundaran P. and Krishnakumar S.: Colloids Surf. A, 1997, 123, 491.

[4] Vandeven T.: Adv. Colloid Interface Sci., 1994, 48, 121.

[5] Somasundaran P. and Yu X.: Adv. Colloid Interface Sci., 1994, 53, 33.

[6] Antonietti M. and Weissenberger M. C.: Macromol. Rapid Comm., 1997, 18, 295.

[7] Zubov V., Serebryakova N., Arutyunov I. et al.: Colloid J., 2004, 66, 302.

[8] Bulychev N., Arutunov I., Zubov V. et al.: Macromol. Chem. Phys., 2004, 205, 2457.

[9] Bulychev N., Dirnberger K., Arutunov I. et al.: Prog. Org. Coat., 2008, 62, 299.

[10] Gray M., Zhou H., Nguyen S. and Torkelson J.: Macromolecules, 2004, 37, 5586.

[11] Van Camp W., Du Prez F. and Bon S.: Macromolecules, 2004, 37, 6673 .

[12] Hoogenboom R., Schubert U., Van Camp W. and Du Prez F.: Macromolecules, 2005, 38, 7653.

[13] Bernaerts K., Willet N., Van Camp W., Jerome R. and Du Prez F.: Macromolecules, 2006, 39, 3760.

[14] Guenzet J.: Chem. Abstr., 1963, 58, 3321.

[15] Nakane Y., Ishidoya M. and Endo T.: J. Polym. Sci. A, 1999, 37, 609.

[16] Couvreur L., Lefay C., Belleney J. et al.: Macromolecules, 2003, 36, 8260 .

[17] Maier H., Baker J. and Berg J.: J. Colloid Interface Sci., $1987,119,512$.

[18] Miller N. and Berg J.: Colloids Surf., 1991, 59, 119.

[19] Carasso M., Rowlands W. and O'Brien R.: J. Colloid Interface Sci. 1997, 193, 200.
[20] O’Brien R.: Part. Syst. Char., 2002, 19, 186.

[21] Schaller C., Schoger A., Dirnberger K. et al.: Macromol. Symp., 2002, 179, 173.

[22] Schaller C., Schauer T., Dirnberger K. and Eisenbach C.: Eur. Phys. J. E, 2001, 6, 365.

[23] Schaller C., Dirnberger K., Schauer T. and Eisenbach C.: Macromol. Symp.: 2002, 187, 695.

[24] Bulychev N., Confortini O., Kopold P. et al:: Polymer, $2007,48,2636$.

\section{СИНТЕТИЧНІ БЛОЧНІ КОПОЛІМЕРИ АКРИЛОВОЇ КИСЛОТИ ЯК РЕАГЕНТИ ДЛЯ МОДИФІКУВАННЯ ПОВЕРХНІПІГМЕНТІВ}

Анотація. Детально досліджено вплив молекулярної архітектури і складу блочних кополімерів на їх поведінку на границі розподілу фаз. Вивчено прочес модифікації поверхні гідрофільного пігменту діоксиду титану $i$ гідрофобного пігменту фталочианіна міді у водному середовищі за допомогою ряду амфіфільних блочних кополімерів. Як стабілізатори використані амфіфільні блочні кополімери, які складаються $з$ поліізоборнілакрилату і поліакрилової кислоти з добре охарактеризованою молекулярною структурою, контрольованою молекулярною масою та вузьким молекулярно-масовим розподілом, синтезовані радикальною полімеризачією 3 переносом атому з використанням макроінічіатора (для одержання блочних кополімерів). Методом електрокінетичної звукової амплітуди вивчені властивості дисперсних систем у відсутності та за наявності ультразвукового впливу. Одержані результати вказують на суттєве збільшення кількості адсорбованого полімеру після ультразвукової обробки, щуо пояснюеться активачією поверхні частинок пігменту.

Ключові слова: дисперсні системи пігментів, блочні кополімери, амфіфільні кополімери, адсорбиія полімеру, ультразвуковий вплив, метод електрокінетичної звукової амплітуди, седиментачія, модифікачія поверхні пігментів. 
